BENELEX Working Paper No 17

\title{
The Evolving Relationship between the Convention on Biological Diversity and International Human Rights Law
}

\author{
Elisa Morgera
}

This paper is part of the project "BENELEX: Benefit-sharing for an equitable transition to the green economy - the role of law," which is funded by the European Research Council Starting Grant (November 2013-October 2018) - Grant Number: 335592:

http://www.strath.ac.uk/research/strathclydecentreenvironmentallawgovernance/ourwork/research/be nelexproject/.
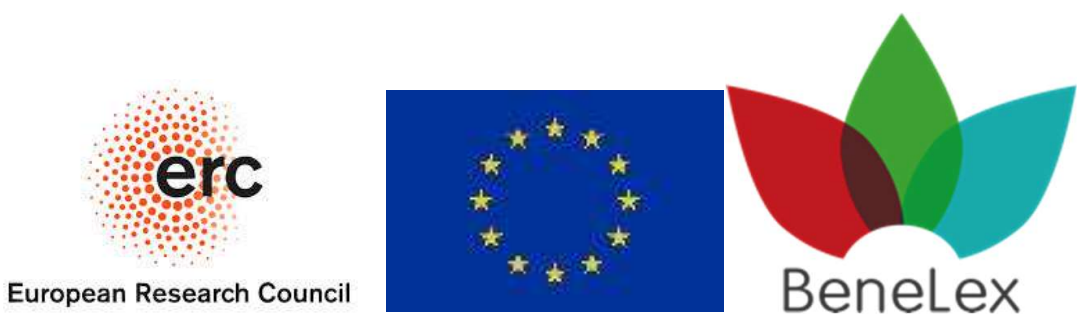

UNIVERSITY of STRATHCLYDE

CENTRE FOR

ENVIRONMENTAL LAW

AND GOVERNANCE 


\title{
DAWN OF A NEW DAY? THE EVOLVING RELATIONSHIP BETWEEN THE CONVENTION ON BIOLOGICAL DIVERSITY AND INTERNATIONAL HUMAN RIGHTS LAW
}

\author{
Elisa Morgera
}

\section{INTRODUCTION}

The Convention on Biological Diversity ("CBD") 1 aims at the conservation of the variability of living organisms ${ }^{2}$ and their interactions, and the sustainable use of living natural resources, encompassing genetic resources and associated traditional knowledge. It also concerns the use of nonliving natural resources that may affect biodiversity conservation and sustainable use, including climate change mitigation and adaptation measures. ${ }^{3}$ In 2014, I argued that against all odds the CBD made significant conceptual and normative contributions to the relationship between human rights and the environment, specifically with regard to indigenous peoples' rights to natural resources. ${ }^{4}$ These contributions also clarified the normative content of due diligence in the context of the business responsibility to respect human rights. ${ }^{5}$ These contributions resulted from the procedural openness to inputs from indigenous peoples in negotiations under the $\mathrm{CBD}^{6}$ as well as the commitment of CBD parties to adopt consensus decisions. Such consensus, however, came at the cost of qualified language ${ }^{7}$ with a view to maintaining a very wide margin of discretion in interpretation and implementation. Today, these developments remain to be studied in more depth from a human rights perspective, as the

1. Convention on Biological Diversity, June 5, 1992, 1760 U.N.T.S. 79.

2. This article will use the definition of biodiversity as defined in CBD Article 2 as "the variability among living organisms from all sources including, inter alia, terrestrial, marine and other aquatic ecosystems and the ecological complexes of which they are part; this includes diversity within species, between species and of ecosystems."

3. Elisa Morgera, Against All Odds: The Contribution of the Convention on Biological Diversity to International Human Rights Law, in UNITY AND DIVERSITY OF INTERNATIONAL LAw: ESSAYS IN HONOUR OF PROFESSOR PIERRE-MARIE DUPUY 983 (Denis Alland et al. eds., 2014), at 983-95.

4. See generallyMorgera, supra note 3 .

5. This was also expanded upon in Elisa Morgera, Benefit-Sharing as a Bridge between Human Rights and the Environment and Human Rights Accountability of Multinational Corporations, in ENVIRONMENTAL LAW DIMENSIONS OF HUMAN RighTS 37-68 (Ben Boer ed., 2015).

6. Under the CBD Working Group on Article 8(j) (traditional knowledge), the fullest possible participation of indigenous and local communities is ensured in all Working Group meetings, including in contact groups, by welcoming community representatives as Friends of the Co-Chairs, Friends of the Bureau and Co-Chairs of contact groups; without prejudice to the applicable rules of procedure of the Conference of the Parties establishing that representatives duly nominated by parties are to conduct the business of CBD meetings so that any text proposal by indigenous and local communities' representatives must be supported by at least one party. Conference of the Parties to the Convention on Biodiversity, Report of the Seventh Meeting of the Ad Hoc Open-Ended Working Group on Article 8(j) and Related Provisions of the Convention on Biological Diversity, I 20, U.N. Doc. UNEP/CBD/COP/11/7 (Nov. 24, 2011), https://www.cbd.int/doc/meetings/cop/cop-11/official/cop-11-07-en.pdf.

7. See Elisa Morgera \& Elsa Tsioumani, Yesterday, Today, and Tomorrow: Looking Afresh at the Convention on Biological Diversity, 21 Y.B. INT'L ENVTL. L. 3 (2011). 
prevailing view remains that the $\mathrm{CBD}$ and its instruments do not engage explicitly with human rights language and concepts. ${ }^{8}$ On the contrary, the reticence of CBD parties to embrace human rights should be seen, in and of itself, as an object of study that can help better understand individual countries' interpretations of international human rights law. Negotiations under the CBD, for instance, highlight continued opposition to "free, prior informed consent" of indigenous peoples ${ }^{9}$ and the broader relevance ${ }^{10}$ of the UN Declaration on the Rights of Indigenous Peoples, ${ }^{11}$ notwithstanding its intervening universal endorsement. ${ }^{12}$

However, over the past five years, the relationship between the CBD and international human rights law has been brought to a whole new level. The increasing reliance on the CBD and its instruments of the Inter-American Court of Human Rights, as well as the work of the UN Special Rapporteur on Human Rights and the Environment, have shed new light on the role of the CBD in ensuring the protection, respect, and realization of human rights. This Article will assess the degree to which the relationship between the $\mathrm{CBD}$ and international human rights law has been clarified and why this relationship matters. It will also analyze the legal arguments advanced by those CBD parties that wish to keep some distance between these two bodies of international law and identify the opportunities that can be missed in ongoing work under the CBD.

\section{INTERNATIONAL HUMAN Rights LAW DEVELOPMENTS RELYING ON THE CBD}

The 2017 report of the UN Special Rapporteur on Human Rights and the Environment ${ }^{13}$ focusing on biodiversity and ecosystem service ${ }^{14}$ can certainly be considered a landmark for the CBD. For the

8. E.g., PATriCia Birnie ET AL., InTERnAtional LAW AND ThE ENVIRONMENT 617, 627 (3d ed. 2009); see, e.g., U.N. Permanent Forum on Indigenous Issues, Rep. of the Tenth Session of the U.N. Permanent Forum on Indigenous Issues, 99 26-27, U.N. Doc. E/2011/43-E/C.19/2011/14 (May 16-27, 2011); see also James Anaya (Special Rapporteur on the Rights of Indigenous Peoples), Report of the Special Rapporteur on the Rights of Indigenous Peoples, I 58, U.N. Doc. A/67/301 (Aug. 13, 2012).

9. See Nagoya Protocol on Access to Genetic Resources and the Fair and Equitable Sharing of Benefits Arising from their Utilization to the Convention on Biological Diversity, art. 7, Oct. 29, 2010, U.N. Doc. UNEP/CBD/COP/DEC/X/1 (entered into force Oct. 12, 2014) (resulting in the adoption of the ambiguous expression "prior informed consent or approval and involvement"). Note that the U.N. Permanent Forum on Indigenous Issues stated that the term "consultation" cannot replace or undermine the right of indigenous peoples to prior informed consent. See Rep. on the Tenth Session of the U.N. Permanent Forum on Indigenous Issues, supra note 8, ๆ 36.

10. E.g., Nagoya Protocol, supra note 9, at preambular recital para. 26; Morgera \& Tsioumani, supra note 7, at 15-16, $18-23$.

11. G.A. Res. 61/295, Declaration on the Rights of Indigenous Peoples (Sept. 13, 2007).

12. The adoption of the Declaration by the General Assembly was initially opposed by Australia, Canada, the US, and New Zealand. All these countries reversed their position by 2010. See Press Release, U.N. Human Rights Office of the High Comm'r, Indigenous Rights Declaration Endorsed by States (Dec. 23, 2010), http://www.ohchr.org/EN/NewsEvents/Pages/Indigenousrightsdeclarationendorsed.aspx.

13. John H. Knox (Special Rapporteur on Human Rights and the Environment), Report of the Special Rapporteur on the Issue of Human Rights Obligations Relating to the Enjoyment of a Safe, Clean, Healthy and Sustainable Environment, U.N. Doc. A/HRC/34/49 (Jan. 19, 2017).

14. Ecosystem services are the benefits people obtain from ecosystems, such as: food, water, timber, and fiber; regulating services that affect climate, floods, diseases, wastes, and water quality; cultural services that provide recreational, aesthetic, and spiritual benefits; and supporting services such as soil formation, photosynthesis, and nutrient cycling. See

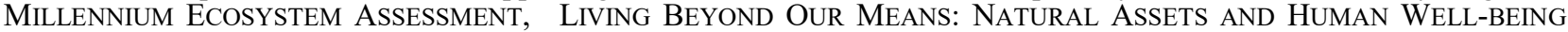
(2005), https://www.millenniumassessment.org/en/BoardStatement.html. Note that in 2017, the Intergovernmental Platform on Biodiversity and Ecosystem Services (IPBES) is now referring to the term "nature's contributions to people" to refer to "all the positive contributions or benefits, and occasionally negative contributions, losses or detriments, that people obtain from nature' and 'explicitly embracing concepts associated with other worldviews on human-nature relations and knowledge systems." IPBES, Implementation of the First Work Programme of the Platform art. III, ๆף 8-9, IPBES- 
first time, CBD obligations have been authoritatively assessed as a matter of international human rights law, based on the unequivocal understanding that the full enjoyment of everyone's human rights to life, health, food, and water depend on healthy ecosystems and their benefits to people. ${ }^{15}$ In other words, the protection and realization of basic human rights depend on successful efforts to prevent biodiversity loss. ${ }^{16}$ Not only did Special Rapporteur Knox make references to the well-understood role of biodiversity as a reservoir of infinite potential for the development of new medicinal and food products, but he also discussed the often-undervalued importance of biodiversity for mental health. ${ }^{17}$ He further underscored more subtle relationships between human well-being and biodiversity, such as the relationship between healthy pollinators and global food security. ${ }^{18}$ This multi-faceted recognition of the implications of biodiversity underpins the role of civil and political rights in the context of biodiversity conservation and sustainable use. Special Rapporteur Knox highlighted that States' efforts to increase and make available information on biodiversity, as well as to ensure public participation in relevant decision-making processes and access to justice in biodiversity-related matters, should be seen as international human rights obligations. ${ }^{19}$ In particular, States need to make more of an effort to protect biodiversity defenders because those protecting endangered species, as exemplified by Special Rapporteur Knox, are doing so to the benefit of human rights. ${ }^{20}$ These clarifications are particularly significant to move away from an understanding of the procedural dimensions of biodiversity conservation and sustainable use ${ }^{21}$ as mere good governance. ${ }^{22}$ These clarifications further assist in understanding international human rights law obligations as limitations to the discretion of CBD parties in their interpretation and implementation of otherwise open-ended treaty language. These clarifications are also noteworthy because of limited research on general, procedural human rights in the context of the CBD. ${ }^{23}$

In addition, Special Rapporteur Knox clarified that there are substantive human rights law obligations that serve to clarify the limits of State discretion in pursuing the CBD objectives relating to biodiversity conservation and sustainable use. ${ }^{24}$ This acknowledgment has two implications. At the domestic level, in authorizing any activity, either conservation or use, CBD parties are to ensure that no unjustified, foreseeable infringements of human rights may arise from the decision. ${ }^{25}$ This is both based on potential public interventions that may infringe biodiversity-dependent human rights and on States' obligation to prevent business entities from violating these rights. ${ }^{26}$ In other words, implementing the CBD obligations in a mutually supportive way with international human rights law clarifies that States must develop laws and institutions that effectively "regulate harm to biodiversity from private actors as well as government entities" in a way that is "non-retrogressive and non-

5/1 (2017); Unai Pascual et al., Valuing Nature's Contributions to People: The IPBES Approach, 26-27 CURRENT OPINION IN ENVTL. SUSTAINABILITY 7, 15, 8-9 (2017).

15. Knox, supra note $13,95$.

16. Id.

17. Id. 12 . 12.

18. Id. ๆๆ 11-20.

19. Id. 9 9 $27-32$.

20. Id. ๆ $31-32,68$.

21. Id. 67.

22. Edith Brown Weiss \& Ahila Sornarajah, Good Governance, in MAX Planck ENCYClOPEDIA OF PUBLIC INTERNATIONAL LAW (Rüdiger Wolfrum ed., 2012).

23. Lalanath de Silva, Public Participation in Biodiversity Conservation, in ElGAR ENCYCLOPEDIA OF ENVIRONMENTAL LAW: Biodiversity AND NATURE Protection LAW 468, 471-74 (Elisa Morgera \& Jona Razzaque eds., 2017).

24. Knox, supra note $13, \mathbf{q} 34$.

25. Id.

26. Id. ๆๆ 33-34. 
discriminatory." 27 These are crucial indications about the minimum content of the international obligations contained in the CBD, which tend to be agnostic about specific means of implementation.

At the multilateral level, Special Rapporteur Knox has indicated that inter-State cooperation on biodiversity also has human rights implications. ${ }^{28}$ This implies both that donor States' duties to support biodiversity efforts in developing countries are relevant to realize human rights dependent on biodiversity and that such support should not be carried out in a way that may lead to violations of other human rights. ${ }^{29}$ While the latter issue has already been addressed to some extent by CBD parties, with an explicit reference to the relevant international human rights instruments, ${ }^{30}$ the former issue remains a matter for further study. ${ }^{31}$ In his Framework Principles on Human Rights and the Environment, Special Rapporteur Knox further clarified that the human rights implications of the international duty to cooperate also entail deeper forms of engagement under multilateral environmental agreements, as well as consideration of the linkages between international environmental law, including international biodiversity law and human rights in the context of international trade and investment agreements. ${ }^{32}$ While trade and investment an area that has already attracted research, ${ }^{33}$ there is still little reflection on the duty to cooperate under multilateral environmental agreements. ${ }^{34}$ One angle that can serve to further clarify the relationship between CBD obligations on financing, technology transfer, capacity building, information-sharing and scientific cooperation, and human rights, for instance, is provided by the ongoing efforts to clarify the normative content of the human right to science. ${ }^{35}$

\section{A. Indigenous Peoples' Rights}

The work of the UN Special Rapporteur on Human Rights and the Environment focused on those most vulnerable to biodiversity loss, notably indigenous peoples ${ }^{36}$ that are uniquely dependent on biological resources for their material and cultural needs. ${ }^{37}$ As a result, one of the most original elements in the Framework Principles on Human Rights and the Environment is Framework Principle 15 , which is also the Principle that draws the most from the CBD. ${ }^{38}$

27. $I d .969$

28. Id. $96-48$

29. Id. 70

30. Conference of the Parties to CBD Dec. XII/3, U.N. Doc. UNEP/CBD/COP/DEC/XII/3, annex 3, I 3(b)-(c) (Oct. 6-17, 2014) [hereinafter COP CBD Dec. XII/3]; see Claudia Ituarte-Lima et al., Safeguards in Scaling-up Biodiversity Financing and Possible Guiding Principles, U.N. Doc. UNEP/CBD/COP/11/INF/7 (Oct. 7, 2012); CLAUDIA ITUARTE-LIMA ET AL., BIODIVERSITY FINANCING AND SAFEGUARDS (2014), http://swed.bio/wp-content/uploads/2015/12/Ituarte-LimaSchultzetal2014cop-12-inf-27-en.pdf.

31. COP CBD Dec. XII/3, supra note $30, \uparrow 1$.

32. Knox, supra note 13, Ф9 36-39.

33. E.g., Elisa Morgera, The Promotion of Environmental Rights through the Bilateral Agreements of the European Union: Mapping the Field, in INTERNATIONAL LAW FOR COMMON GOODS 421-41 (Lenzerini \& Vrdoljak eds., 2014).

34. COP CBD Dec. XII/3, supra note $30, \uparrow 1$.

35. Elisa Morgera, Fair and Equitable Benefit-Sharing at the Crossroads of the Human Right to Science and International Biodiversity Law, 4 LAWS 803-31 (2015).

36. Note that the UN Special Rapporteur also raised the issue of other communities than indigenous ones that are entitled to similar protection under international law. See Elisa Morgera, A Reflection on Benefit-sharing as a Framework Principle on Human Rights and the Environment Proposed by UN Special Rapporteur John Knox (Part II: Right-holders and Duty-bearers), BENELEX BLOG (Apr. 8, 2018), https://benelexblog.wordpress.com/2018/04/08/a-reflection-on-benefitsharing-as-a-framework-principle-on-human-rights-and-the-environment-proposed-by-un-special-rapporteur-john-knoxpart-ii-right-holders-and-duty-bearers/.

37. Knox, supra note 13, ๆ9 22-25, 49-64.

38. The following discussion is based on Elisa Morgera, A Reflection on Benefit-sharing as a Framework Principle on Human Rights and the Environment proposed by UN Special Rapporteur John Knox (Part I), BENELEX BLOG (Apr. 8, 
Framework Principle 15 concerns the use of lands, territories, and resources that are traditionally owned, occupied, or used by indigenous peoples, including those to which they have had access for their subsistence and traditional activities, even when they not have formal recognition of property rights or delimitation and demarcation of boundaries. ${ }^{39}$ These resources are linked to indigenous peoples' traditional knowledge and genetic resources. ${ }^{40}$ Framework Principle 15 entails a series of interconnected obligations to ensure indigenous peoples' full and effective participation in decisionmaking on the entire spectrum of matters that affect their lives, including legislative or administrative measures that may affect them directly, programs for the exploration, exploitation or conservation of resources pertaining to their lands or territories, and proposals to alienate lands or territories or otherwise transfer their rights. ${ }^{41}$ These obligations entails consulting with indigenous peoples to obtain their free, prior and informed consent ("FPIC") before taking or approving any measures that may affect their lands, territories, or resources, on the basis of access to all relevant information in understandable and accessible forms ${ }^{42}$ and prior assessments of the environmental and social impacts of proposed measures. ${ }^{43}$ These assessments "should be in accord with the guidelines adopted by the Conference of Parties to the Convention on Biological Diversity," notably the Akwé: Kon Voluntary Guidelines on environmental and socio-cultural assessments. ${ }^{44}$ Furthermore, Framework Principle 15 refers to States' obligations to ensure that indigenous peoples and members of traditional communities "fairly and equitably share the benefits from activities relating to their lands, territories or resources." 45 This obligation is, in turn, connected with the need to respect and protect indigenous peoples' traditional knowledge and practices in relation to the conservation and sustainable use of their lands, territories, resources, ${ }^{46}$ and the environment, including through States' assistance to indigenous peoples' efforts to preserve the productive capacity of their lands, territories, and resources. ${ }^{47}$

The inclusion of benefit-sharing is particularly significant. International human rights law processes have referred to it through inconsistent terminology, while under international biodiversity law the term has been used consistently but is not defined. In both areas, however, it can be argued that "sharing" benefits underscores the agency of beneficiaries and the need to build a genuine partnership among actors whose relationship is characterized by power asymmetries. ${ }^{48}$ In addition, Framework Principle 15 provides the most comprehensive list of benefit-sharing triggers in international human rights law. ${ }^{49}$ Special Rapporteur Knox further clarifies that benefit-sharing must

2018), https://benelexblog.wordpress.com/2018/04/08/a-reflection-on-benefit-sharing-as-a-framework-principle-onhuman-rights-and-the-environment-proposed-by-un-special-rapporteur-john-knox-part-i/.

39. Knox, supra note 13, Ф甲 53, 48.

40. Id. ๆ53.

41. Id. 90.

42. Which is linked to Knox's Framework Principles 7 and 8. Id. at Framework Principle 7, 8.

43. Id. $\ 20$.

44. Conference of the Parties to CBD Dec. VII/16, U.N. Doc. UNEP/CBD/COP/DEC/VII/16, annex, § F (Apr. 13, 2014) [hereinafter Akwé: Kon Guidelines]; Knox, supra note 13, \ 43.

45. Knox, supra note 13, at Framework Principle 15(d).

46. Id. 152

47. Id.

48. Elisa Morgera, Under the Radar: Fair and Equitable Benefit-Sharing and the Human Rights of Indigenous Peoples and Local Communities Related to Natural Resources at 8 (BENELEX, Working Paper No. 10 rev, 2018) http://ssrn.com/abstract=2887803. Benefit-sharing under international biodiversity and human rights law can be thus defined as concerted and dialogic partnership-building in identifying and allocating economic, socio-cultural, and environmental benefits among State and non-State actors, with an emphasis on the vulnerable. See Elisa Morgera, The Need for an International Legal Concept of Fair and Equitable Benefit-Sharing 27 EUROPEAN J. INT'L L. 383 (2016) [hereinafter Morgera, The Need]

49. Morgera, The Need, supra note 48, at 372-78. 
be consistent with indigenous peoples' and traditional communities' own priorities. ${ }^{50} \mathrm{He}$ implicitly links it to the need for recognition of rights to the lands, territories, and resources that they have traditionally owned, occupied, or used as well as due respect for the customs, traditions, and land tenure systems of the peoples or communities concerned, and effective remedies for violations of rights. ${ }^{51}$ Special Rapporteur Knox substantiated benefit-sharing on the basis of the particular vulnerability of indigenous peoples to environmental harm "because of their close relationship with the natural ecosystems on their ancestral territories." 52

Overall, Principle 15 reflects the cross-fertilization between international human rights law and international biodiversity law fostered by the work of former UN Special Rapporteur on Indigenous Peoples' Rights, James Anaya ${ }^{53}$ and the seminal case law of the Inter-American Court on Human Rights. ${ }^{54}$ Both have relied on decisions adopted under the CBD. ${ }^{55}$ The Inter-American Court initially made a reference to the CBD Akwe: Kon Guidelines as the "relevant international standards and best practice" in a footnote ${ }^{56}$ in determining that extractive activities on indigenous peoples' lands can only proceed after an environmental and socio-cultural impact assessment, FPIC, and benefit-sharing. ${ }^{57}$ In the 2015 Kaliña \& Lokono ${ }^{58}$ decision, the court was much more explicit about the need for, and merits of, mutual supportiveness with consensus guidance adopted under the CBD. ${ }^{59}$ It underscored States' obligations to protect, in a manner compatible with their international environmental obligations, indigenous peoples' rights to a dignified life and to cultural identity connected with natural resources in their traditional territories. ${ }^{60}$ In support of this interpretation, it cited the expert opinion of then UN Special Rapporteur on the Rights of Indigenous Peoples, Victoria Tauli-Corpuz, as follows:

International environmental law and international human rights law should not be considered separate, but rather interrelated and complementary, bodies of law. Indeed, the States Parties to the Convention on Biological Diversity (CBD) have incorporated respect for the related international rights and obligations into their decision on protected areas in relation to indigenous peoples.... The CBD, and its authorized interpretation by the Conference of the Parties, defends fully the rights of the indigenous peoples in relation to the protected areas and requires that these are established and managed in full compliance with the State's international obligations. This permits the application of the whole range of the State's human

50. Knox, supra note 13 , 953 10.

51. Id. ๆฯ 47-49, 53. Framework Principle 10 makes clear what "effective remedies" entail. Id. at Framework Principle

52. Id. 947.

53. Elisa Morgera, The Legacy of UN Special Rapporteur Anaya on Indigenous Peoples and Benefit-sharing, BENELEX BLOG (May 29, 2014), https://benelexblog.wordpress.com/2014/05/29/the-legacy-of-un-special-rapporteur-anaya-onindigenous-peoples-and-benefit-sharing/.

54. See, e.g., Case of the Saramaka People v. Suriname, Preliminary Objections, Merits, Reparations, and Costs, Judgment, Inter-Am. Ct. H.R. (ser. C) No. 185, $₫ 41$ (Aug. 12, 2008).

55. See id.; James Anaya (Special Rapporteur on the Rights of Indigenous Peoples), Measures Needed to Secure Indigenous and Tribal Peoples' Land and Related Rights in Suriname, q1 8-12, U.N. Doc. A/HRC/18/35/Add.7 (Aug. 18, 2011).

56. Case of the Saramaka People, Inter-Am. Ct. H.R. (ser. C) No. 185, supra note 54, 941.

57. Id.

${ }^{58}$ Case of the Kaliña \& Lokono Peoples v. Suriname, Merits, Reparations and Costs, Judgment, Inter-Am. Ct. H.R. (ser. C) No. 309, \172 (Nov. 25, 2015).

59. Id. at 9 173-74, 177-78, 181, 214 n.247 (referencing Conference of the Parties to CBD Dec. VII/12, U.N. Doc. $\mathrm{UNEP} / \mathrm{CBD} / \mathrm{COP} / \mathrm{DEC} / \mathrm{VII} / 12$, annex II (Apr. 13, 2004) [hereinafter COP CBD Dec. VII/12], and Conference of the Parties to CBD Dec. VII/28, U.N. Doc. UNEP/CBD/COP/DEC/VII/28, annex (Apr. 13, 2004) [hereinafter COP CBD Dec. VII/28]); Convention on Biological Diversity, supra note 1, arts. 8(j), 10, 14.

60. Case of the Kaliña \& Lokono Peoples, Inter-Am. Ct. H.R. (ser. C) No. 309, supra note 58, ๆף 181, 193. 
rights obligations as defined by the American Convention on Human Rights and established in the UN Declaration. It is also the consensus reflected in the main international policy norms and best practice.... The [UN] Rapporteur has adhered to these same basic principles affirmed by the Human Rights Committee and the Committee for the Elimination of Racial Discrimination. ${ }^{61}$

The Inter-American Court, therefore, appears to consider the consensus decisions adopted by CBD parties as interpretative tools not only for the purposes of the CBD itself but also for a mutually supportive interpretation of relevant international human rights law. Accordingly, it relied on CBD Articles 8(j) and 10(c) addressing indigenous peoples' traditional knowledge and their customary sustainable use of biological resources, as well as the CBD program of work on protected areas, ${ }^{62}$ to identify safeguards for establishing conservation measures on traditional lands. These safeguards comprise effective participation, access and use of their traditional territories, and benefit-sharing, provided that they are compatible with protection and sustainable use. ${ }^{63}$ Furthermore, the court found that the absence of explicit mechanisms that guarantee benefit-sharing from conservation measures is a violation of political rights, relying on the CBD obligation on environmental impact assessments. ${ }^{64}$

This confirms that CBD decisions, even if they do not employ human rights terminology, provide helpful guidance for the interpretation and implementation of international human rights standards concerning indigenous and tribal peoples. It equally shows that while State discretion is quite wide in implementing the $\mathrm{CBD}$, applicable international human rights law restricts such discretion and provides for minimum guarantees whenever indigenous peoples are concerned. The reflection of this case law into the UN Framework Principles corroborates the view expressed by the Inter-American Court that benefit-sharing obligations are also implicit in global human rights instruments, ${ }^{65}$ and this interpretation is therefore relevant for other regions. ${ }^{66}$

\section{CBD DeVelopments of ReleVAnCe to InTERnational Human Rights LaW}

Despite the doubts that may arise from the open-ended language and lack of explicit references to human rights in the CBD and the guidelines adopted under it, the discussion above indicates that CBD instruments nevertheless provide useful guidance on implementation that cannot be found in the relevant international human rights law sources. This Part will explore this point further through two examples that serve to illustrate the significant level of operational detail that CBD instruments can offer to rather abstract international human rights obligations by placing them in the specific context of natural resource management and planning. The two examples are the above-cited Akwé: Kon Guidelines on environmental and socio-cultural assessments and the more recent Mo'otz Kuxtal Voluntary Guidelines on consent and benefit-sharing from the use of traditional knowledge. ${ }^{67}$

61. Id. 174 (emphasis added).

62. Id. 9 甲 178, 214 n.247; COP CBD Dec. VII/28, supra note 59.

63. Case of Kaliña \& Lokono Peoples, Inter-Am. Ct. H.R. (ser. C) No. 309, supra note 58, ๆ 181.

64. Id. 197 (relying on Convention on Biological Diversity, supra note 1, art. 14).

65. Case of the Saramaka People v. Suriname, Preliminary Objections, Merits, Reparations and Costs, Judgment, InterAm. Ct. H.R. (ser. C) No. 172, 95 (Nov. 28, 2007) (referencing International Covenant on Civil and Political Rights (ICCPR), arts. 1 and 27, Dec. 26, 1966, 999 U.N.T.S. 171 and International Covenant on Economic, Social and Cultural Rights (ICESCR), art. 1, Dec. 16, 1966, 993 U.N.T.S. 3).

66. Morgera, supra note 38 .

67. The Mo'otz Kuxtal Voluntary Guidelines for the development of mechanisms, legislation or other appropriate initiatives to ensure the "prior and informed consent," "free, prior and informed consent," or "approval and involvement," depending on national circumstances, of indigenous peoples and local communities for accessing their knowledge, innovations and practices, for fair and equitable sharing of benefits arising from the use of their knowledge, innovations and practices relevant for the conservation and sustainable use of biological diversity, and for reporting and preventing 


\section{A. Akwé: Kon Guidelines}

The Akwé: Kon Guidelines have been relied upon in the international human rights context because they provide concrete and systematic indications on how impact assessments should be conducted. They clarify that processes should be established for recording indigenous communities' views, including when they are unable to attend public meetings because of remoteness or poor health, as well as the usage of non-written forms. ${ }^{68}$ In addition, governments should provide sufficient human, financial, technical, and legal resources to support indigenous expertise proportionally to the scale of the proposed development, and indigenous communities should be involved in the financial auditing processes of the development so that the resources invested are used effectively. ${ }^{69}$

Besides step-by-step guidance to implementation, the Akwé: Kon Guidelines further provide hooks for more transformative changes in impact assessment practices. The integration of benefitsharing as part of the assessment, ${ }^{70}$ for instance, arguably helps move away from an exclusive focus on "damage control" 71 that tends to characterize these exercises. Consideration of benefits rather calls for a systematic consideration of positive implications, not only negative impacts (such as potential damage to ways of life, livelihoods, well-being, and traditional knowledge), of proposed developments. ${ }^{72}$ Thus, the Akwé: Kon Guidelines focus on elements that can support considering benefits from indigenous peoples' perspective, such as food, health, environmental sustainability, and community well-being, vitality and viability (employment levels and opportunities, welfare, education, and availability and standards of housing, infrastructure, services). ${ }^{73}$ With that, the Guidelines may "open up" the assessment to different worldviews in order to take into account, in an integrated manner, indigenous peoples' rights over lands and waters traditionally occupied or used by them and associated biodiversity. ${ }^{74}$ The Guidelines do so by calling for the assessment of the following cultural aspects: beliefs systems, languages and customs, traditional systems of natural resource use, maintenance of genetic diversity through indigenous customary management, exercise of customary laws regarding land tenure, and distribution of resources and benefits of transgenerational aspects, including opportunities for elders to pass on their knowledge to youths. ${ }^{75}$

It should also be noted that the Akwé: Kon Guidelines have influenced the practice of international corporate accountability mechanisms. For instance, the UK National Contact Point used the Akwé: Kon Guidelines to interpret the Organization for Economic Co-operation and Development ("OECD") Guidelines for Multinational Enterprises ${ }^{76}$ to determine that a mining company did not employ culturally adequate means of communication to consult with indigenous communities with a very high

unlawful appropriation of traditional knowledge. Conference of the Parties to CBD Dec. XIII/18, U.N. Doc. UNEP/CBD/COP/DEC/XIII/18, Mo'otz Kuxtal Voluntary Guidelines (Dec. 17, 2016) [hereinafter Mo'otz Kuxtal Voluntary Guidelines].

68. Akwé: Kon Guidelines, supra note 44, 17.

69. Id. ๆ 18

70. Id. 9 बा $34,40$.

71. Morgera, supra note 38; see also Neil Craik, Biodiversity-Inclusive Impact Assessment, in ENCYCLOPEDIA OF ENVIRONMENTAL LAW: BIODIVERSITY AND NATURE PROTECTION LAW 431, 431-44 (Elisa Morgera \& Jona Razzaque eds., 2017).

72. Akwé: Kon Guidelines, supra note 44, ๆๆ 42-43.

73. Id. ๆ 40

74. Morgera, supra note 38.

75. Akwé: Kon Guidelines, supra note 44, ๆథ 24, 49.

76. See generally OECD, Foreword to OECD GUIDELINES FOR MULTINATIONAL ENTERPRISES (2011) ("The OECD Guidelines for Multinational Enterprise are recommendations . . . . They provide non-binding principles and standards for responsible business conduct in a global context."). 
rate of illiteracy. ${ }^{77}$ The Akwé: Kon Guidelines were equally relied upon by the UN Special Rapporteur on Indigenous Peoples' Rights ${ }^{78}$ in interpreting the UN Framework on Business and Human Rights. ${ }^{79}$ Along similar lines, the Expert Mechanism on the Rights of Indigenous Peoples stressed the link between FPIC, benefit-sharing, and mitigation measures in the context of large-scale natural resource extraction on indigenous peoples' territories on the basis of the CBD work program on protected areas and the Akwé: Kon Guidelines. ${ }^{80}$ More recently, Special Rapporteur Knox has recommended that private companies involved in conservation also respect the Akwé: Kon Guidelines. ${ }^{81}$

\section{B. Mo'otz Kuxtal Guidelines}

A more recent contribution from the CBD to international human rights law can be found in the 2016 Mo'otz Kuxtal Guidelines on consent and benefit-sharing from the use of traditional knowledge of indigenous peoples. A remarkably collaborative and frank exchange of ideas between parties and non-State actors characterized the negotiations on these guidelines, ${ }^{82}$ with a great number of suggestions made by indigenous peoples' representatives incorporated into this instrument. ${ }^{83}$

Nonetheless, unequivocal reliance on international human rights language (notably from the UN Declaration on Indigenous Peoples' Rights) remained very controversial, as demonstrated by protracted contention over whether to use the expression "free prior informed consent." 84 Due to the inability of national delegations to find consensus on this point, the Guidelines eventually make reference to "the "prior and informed consent," "free, prior and informed consent" or "approval and involvement," depending on national circumstances." 85 One explanation for the awkward wording can be found in the Guidelines themselves, which note that it would be "not practical to propose a "one-

77. Final Statement by the UK National Contact Point for the OECD Guidelines for Multinational Enterprises: Complaint from Survival International Against Vedanta Resources plc, UK National Contact Point for the OECD Guidelines for Multinational Enterprises 9 44-46, (Sept. 25, 2009), https://www.oecd.org/corporate/mne/43884129.pdf.

78. James Anaya (Special Rapporteur on the Situation of Human Rights and Fundamental Freedoms of Indigenous People), Report of the Special Rapporteur on the Situation of Human Rights and Fundamental Freedoms of Indigenous People, 9 19 73-75, U.N. Doc. A/HRC/15/37 (July 19, 2010).

79. See John Ruggie (Special Representative of the Secretary-General on the Issue of Human Rights and Transnational Corporations and Other Business Enterprises), Protect, Respect and Remedy: A Framework for Business and Human Rights, U.N. Doc. A/HRC/8/5 (Apr. 7, 2008) (endorsed by the Human Rights Council in Res. 8/7, 9ף 1-2, 4(g), U.N. Doc. A/HRC/RES/8/7 (June 18, 2008)); see also John Ruggie (Special Representative of the Secretary-General on the Issue of Human Rights and Transnational Corporations and Other Business Enterprises), Guiding Principles on Business and Human Rights: Implementing the United Nations "Protect, Respect and Remedy" Framework, - 6-9, U.N. Doc. A/HRC/17/31 (Mar. 21, 2011) (adopted by the Human Rights Council Res. 17/4, 991 1-4, U.N. Doc. A/HRC/RES/17/4 (July $6,2011)$.

80. José Carolos Morales (Expert Mechanism on the Rights of Indigenous Peoples), Progress Report on the Study on Indigenous Peoples and the Right to Participate in Decision-making, 99 34-38, U.N. Doc. A/HRC/15/35 (Aug. 23, 2010); José Carlos Morales (Expert Mechanism on the Rights of Indigenous Peoples), Report of the Expert Mechanism on the Rights of Indigenous Peoples on its Third Session, Geneva (12-16 July 2010), 9ף 29-58, U.N. Doc. A/HRC/15/36 (Aug. 23, 2010)

81. Knox, supra note $13, \mathbf{q} 72$.

82. Elisa Morgera, Towards International Guidelines on Prior Informed Consent and Fair and Equitable Benefitsharing from the Use of Traditional Knowledge, BENELEX BLOG (Dec. 9, 2015), https://benelexblog.wordpress.com/2015/12/09/towards-international-guidelines-on-prior-informed-consent-and-fair-andequitable-benefit-sharing-from-the-use-of-traditional-knowledge/.

83. See Working Group on Art. 8(j) and Related Provisions of CBD, Draft Recommendation Submitted by the CoChairs, U.N. Doc. UNEP/CBD/WG8J/9/L.5

(Nov. 7, 2014), https://www.cbd.int/doc/meetings/tk/wg8j-09/insession/wg8j-09-1-05-en.doc.

84. Elsa Tsioumani et al., Summary of the UN Biodiversity Conference, 9 EARTH NEGOTIATIONS BULLETIN 678 (Dec. 20, 2016), http://enb.iisd.org/vol09/enb09678e.html.

85. Morgera, supra note 82. 
size-fits-all' approach" since the document is intended to be used "taking into account national and local circumstances of the indigenous peoples and local communities concerned." 86 However, another explanation can be found in the statements made by some governments to the UN Declaration on the Rights of Indigenous Peoples ${ }^{87}$ and their desire to protect room for maneuvering at the national level in regulating their relationships with indigenous peoples.

While the Mo'otz Kuxtal Guidelines fall short of aligning with common terminology in other international processes, they nevertheless contain several elements that serve to explain what "free" prior informed consent means, which remains a controversial matter in international human rights law. ${ }^{88}$ The Mo'otz Kuxtal Guidelines explain that this concept has a number of connotations that go beyond the mere absence of coercion. First, FPIC conveys that indigenous peoples should not be "pressured, intimidated, manipulated or unduly influenced." 89 Second, the understanding of "prior" underscores the need to take into account the time requirements of indigenous peoples' own decisionmaking procedures. ${ }^{90}$ Third, the understanding of "consent or approval" includes the right not to grant consent and only allow the temporary use of traditional knowledge for the purpose for which it was granted unless it was otherwise mutually agreed. ${ }^{91}$ Fourth, the Mo'otz Kuxtal Guidelines provide stepby-step guidance to implement FPIC: the provision of adequate and balanced information from a variety of sources that is made available in indigenous or local languages, to ensure that all parties have the same understanding of the information and terms provided; the submission of a written application in a manner and language comprehensible to the traditional knowledge holder; and a legitimate and culturally appropriate form of decision-making process, including consideration of possible social, cultural and economic impacts. ${ }^{92}$ More fundamentally, the Guidelines emphasize that FPIC is a "continual process of building mutually beneficial, ongoing arrangements between users and holders of traditional knowledge, in order to build trust, good relations, mutual understanding, intercultural spaces, knowledge exchanges, and to create new knowledge and reconciliation." 93 This is a key clarification that consent or approval is an iterative process, not a one-time exercise, which "should underpin and be an integral part of developing a relationship between users and providers of traditional knowledge." 94

All these indications appear helpful in clarifying the international community's expectations about the quality and aims of any interactions among governments, non-State actors, and indigenous peoples. To a significant extent, the Mo'otz Kuxtal Guidelines support the proposition made by indigenous peoples" representatives engaging in their negotiations that "free" serves to imply a process that is "self-directed by the community" from whom consent is sought, with a view to emphasizing the need for communities to control the context of decision-making. ${ }^{95}$

86. Mo'otz Kuxtal Voluntary Guidelines, supra note 67.

87. E.g., Canada's Statement of Support on the United Nations Declaration on the Rights of Indigenous Peoples, INDIGENOUS AND NORTHERN AFFAIRS CANADA (Nov. 12, 2010), https://www.aadncaandc.gc.ca/eng/1309374239861/1309374546142.

88. E.g., MATTIAS ÅRHÉN, INDIGENOUS PEOPLES IN THE INTERNATIONAL LEGAL SYSTEM 217-18 (2016); José Carolos Morales (Expert Mechanism on the Rights of Indigenous Peoples), Follow-up Report on Indigenous Peoples and the Right to Participate in Decision-making, with a Focus on Extractive Industries, U.N. Doc. A/HRC/21/55, q9 38(b), 39(h), 43 (Aug. 16, 2012).

89. Mo'otz Kuxtal Voluntary Guidelines, supra note 67, ๆ 7(a).

90. Id. 9 7(b).

91. Id. (emphasis added).

92. Id. I 7(c).

93. Id. 9 . (internal citations omitted) (emphasis added).

94. Id.

95. Morgera, supra note 35 , at 824 . 
In line with this understanding of consent, the Mo'otz Kuxtal Guidelines emphasize that benefitsharing is also about iterative partnership building, rather than a top-down, one-time or unilateral flow of benefits where indigenous peoples are passive beneficiaries. ${ }^{96}$ These guidelines make reference to partnership and cooperation as principles guiding the process for establishing mutually agreed terms to ensure fair and equitable benefit-sharing with and among traditional knowledge holders. ${ }^{97}$ In addition, they indicate that "benefits should, as far as possible, be shared in understandable and culturally appropriate formats, with a view to building enduring relationships, promoting intercultural exchanges, knowledge and technology transfer, synergies, complementarity and respect." 98 In other words, they hint that FPIC and benefit-sharing are intertwined and geared towards the same aim. Furthermore, the Mo'otz Kuxtal Guidelines draw attention to the role of benefit-sharing in supporting cultural reproduction, by stating that "benefit-sharing could include a way of recognizing and strengthening the contribution of indigenous peoples and local communities to the conservation and sustainable use of biological diversity, including by supporting the intergenerational transmission of traditional knowledge." 99

Similarly to guidance emerging in international human rights law, the Mo'otz Kuxtal Guidelines underscore that benefit-sharing "may vary depending upon the type of benefits, the specific conditions and national legislation in the country where the traditional knowledge was originally accessed, the content of the mutually agreed terms and the stakeholders involved," and benefit-sharing mechanisms "should be flexible" and determined on a case-by-case basis. ${ }^{100}$ In addition, the Mo'otz Kuxtal Guidelines do nevertheless call attention to the needs for information, as part of prior "informed" consent, to be provided on benefit-sharing arrangements and grievance mechanisms.

Concerns about potential inequities at the level of intra-community benefit-sharing that have already been encapsulated in other international guidelines, notably, the Committee on Food Security's Guidance for Responsible Agricultural Investment, ${ }^{101}$ are also addressed. The Mo'otz Kuxtal Guidelines note that "benefit-sharing should be fair and equitable within and among relevant groups, taking into account relevant community level procedures, and as appropriate gender and age/intergenerational considerations." 102

In addition to these conceptual clarifications, these Guidelines also provide operative details to address the crucial question of legal pluralism by devoting significant attention to "community protocols" as tools that:

cover a broad array of expressions, articulations, rules and practices generated by communities to set out how they expect other stakeholders to engage with them. They may reference customary as well as national or international laws to affirm their rights to be approached according to a certain set of standards. ${ }^{103}$

These protocols:

96. Morgera, The Need, supra note 48, at 360.

97. Mo'otz Kuxtal Voluntary Guidelines, supra note 67, $123(\mathrm{a})$

98. Id. $\top 23(\mathrm{c})$.

99. Id. 13.

100. Id. 924.

101. Margherita Brunori, Principles on Responsible Investment in Agriculture and Food Systems: A (very) Critical Analysis, BENELEX BLOG (May 21, 2015), https://benelexblog.wordpress.com/2015/05/21/principles-on-responsibleinvestment-in-agriculture-and-food-systems-a-very-critical-analysis/.

102. Mo’otz Kuxtal Voluntary Guidelines, supra note 67, \14.

103. Id. 19. 
provide communities an opportunity to focus on their development aspirations vis-a-vis their rights and to articulate for themselves and for users their understanding of their bio-cultural heritage and therefore on what basis they will engage with a variety of stakeholders. By considering the interconnections of their land rights, current socio-economic situation, environmental concerns, customary laws and traditional knowledge, communities are better placed to determine for themselves how to negotiate with a variety of actors. ${ }^{104}$

At the initiative of indigenous peoples' representatives, the Mo'otz Kuxtal Guidelines provide an overview of the possible content of community protocols, such as "information about community identity, community history, and community territoriality"; "social organization and decision-making processes (which are often collective decision-making procedures at the community level)"; concerns about the implementation of environmental laws according to customary laws; and concerns about sustainable development on community lands. ${ }^{105}$

Community protocols have been brought to the CBD agenda as a result of the work of the nongovernmental organizations both in local communities and around the international negotiating table ${ }^{106}$ and remain to be studied from an international human rights law perspective. Community protocols may, for instance, create a risk that governments would apply pressure from above to force communities to codify their understandings of benefit-sharing in community protocols and adapt local benefit-sharing norms to international standards that may be exogenously interpreted by governments or outsiders. ${ }^{107}$ Interestingly, during the negotiations of the Mo'otz Kuxtal Guidelines, delegates eventually agreed to eliminate proposed text stating that indigenous peoples may wish to include special measures in their community protocols for encouraging non-commercial research, participatory research, and joint research for conservation and sustainable use, ${ }^{108}$ as this was seen as an example of potential pressure from the outside. Overall, more research remains to be undertaken on the potential of community protocols to inject the CBD and other international fora with local voices to "expand understandings of benefit-sharing beyond the monetary definitions linked to capitalist and colonial logics sometimes assumed to be the benefits of highest interest to local groups" and to "challenge power relations both within and outside communities in order to create spaces for dialogues between discourses." 109

\section{Divergent Views on Legal SignificAnce}

While it is in qualified and often convoluted language, ${ }^{110}$ a body of intergovernmental guidance for the protection of the rights of indigenous peoples has emerged from the CBD and is supported by

104. Id.

105. Id.

106. See Harry Jonas et al., Community Protocols and Access and Benefit-Sharing, 12 ASIAN BIOTECHNOLOGY \& DEV. REV. 49, 63-64 (2010); Emma Jukic \& Neva Collings, Community Protocols for Environmental Sustainability: A Guide for Policymakers 2-9 (2013), http://wedocs.unep.org/handle/20.500.11822/8360?show=full.

107. Louisa Parks, Challenging Power from the Bottom Up? Community Protocols, Benefit-Sharing and the

Challenge of Dominant Discourses, 88 GEOFORUM 87, 88-91 (2018),

https://www.sciencedirect.com/science/article/pii/S0016718517303238.

108. Tsioumani et al., supra note 84, at 13.

109. Parks, supra note 107 , at 92.

110. This is due to the fact that CBD parties' guidance is dispersed throughout a myriad of generally long COP decisions, and within these decisions, relevant passages are not always well organized or clearly separated by topic or addressee. Frequent qualifications and convoluted drafting further undermine the comprehensibility of COP decisions and of their legal implications under the CBD. CBD parties have long complained of the convoluted, repetitious and disorderly style of drafting of the CBD COP decisions. See Conference of the Parties to CBD Dec. X/12, U.N. Doc. $\mathrm{UNEP} / \mathrm{CBD} / \mathrm{COP} / \mathrm{DEC} / \mathrm{X} / 12$, 16 (Oct. 29, 2010). 
the consensus of 196 Parties. ${ }^{111}$ Consensus may have a "powerful law-making effect" by way of "securing widespread support for a text that legitimizes and promotes consistent State practice ...."112 Even if CBD parties have been very careful in labeling relevant decisions as "voluntary" guidelines, this has not prevented the Inter-American Court, for instance, from considering such guidance as an authoritative interpretation of international obligations both under the CBD and relevant international human rights treaties.

This evolutive and mutually supportive interpretation should be contrasted with more recent practice under the $\mathrm{CBD}$ where the voluntary nature of the guidelines tends to be further qualified. For instance, in taking a decision on adopting the terminology "indigenous peoples and local communities" (rather than "indigenous and local communities," which is used in the CBD text itself), CBD parties went to great lengths to indicate that the decision had no implication from the perspective of treaty interpretation (either as subsequent agreement or subsequent practice). ${ }^{113}$ These qualifications have successively been cited in the Mo'otz Kuxtal Guidelines, ${ }^{114}$ to pre-empt limitations to States' discretion in developing national legislation. In addition, the Mo'otz Kuxtal Guidelines indicate that they "do not apply" to traditional knowledge associated with genetic resources under the Nagoya Protocol on Access to Genetic Resources and Benefit-sharing ${ }^{115}$ but "may be used as an input, where appropriate, for the development of specific instruments under the Protocol." 116 This seems to indicate that the Guidelines cannot be seen as an interpretative material for the Nagoya Protocol as a matter of international law, but only as a loose source of inspiration as a matter of domestic implementation. In other words, some CBD parties have sought to limit the international law-making implications of these instruments. Consensus has been reached on the understanding that the Guidelines represent best practice, not authoritative agreement on treaty interpretation.

These developments can be usefully related to the considerations made by Special Rapporteur Knox with regard to the status of progressive development of international law underpinning the UN Framework Principles on Human Rights and the Environment. As Special Rapporteur Knox indicated, the Framework Principles can be seen as "best practices" that serve to "facilitate the implementation" of existing international obligations and that reflect growing "coherence in the interpretation by binding human rights tribunals and authoritative human rights bodies." 117 Further, the Framework Principles provide "strong evidence of the converging trends towards greater uniformity and certainty in ... understanding." 118 Special Rapporteur Knox, therefore, considered that this interpretation "should be accepted as a reflection of actual or emerging international human rights law."119 On the other hand, he cautioned that "not all States have formally accepted" the international norms upon which these coherent interpretations are based, which is particularly significant in the case of emerging, rather than actual, international law. ${ }^{120}$ The qualifications in the CBD guidance can thus be interpreted as an

111. Representing the whole international community, with the exception only of the United States, Andorra, and the Holy See. It should be noted that there is anecdotal evidence that the United States is significantly involved in the CBD process. See Morgera \& Tsioumani, supra note 7, at 4 n. 12 .

112. Alan Boyle \& Christine ChInKIN, ThE MAKING OF InTERNATIONAL LAW 160 (., 2007).

113. See COP CBD Dec. VII/12, supra note 58, § F, ๆ 2(c) (with reference to VCLT article 31(3)(a) and (b) or special meaning as provided for in VCLT article 31(4)). This is without prejudice to the interpretation or application of the Convention in accordance with VCLT Article 31(3)(c).

114. See Mo'otz Kuxtal Voluntary Guidelines, supra note 66, at n.2.

115. Id. at preambular recital para. 8 .

116. Id.

117. Knox, supra note 13, 9 7-8.

118. Knox, supra note $13, \boldsymbol{9} 9$.

119. Id. (emphasis added).

120. Id. 98. 
expression of disagreement among CBD parties as to whether certain interpretations reflect existing or emerging international law, based also on the fact that each individual party to the CBD may not have formally accepted the same underlying international human rights norms. Nevertheless, Special Rapporteur Knox has indicated that the best practice should be "adopt[ed] as expeditiously as possible." 121 In other words, it becomes increasingly difficult for a State to defend an approach that goes against an internationally recognized best practice, particularly when it has agreed upon it after intensely participating in intergovernmental negotiations .

\section{OUTLOOK}

Over the past five years, the once taboo relationship between international human rights law and biodiversity has received increasing attention and has benefitted from a remarkable degree of clarification. Nevertheless, there remain CBD parties that appear worried about the limitations to their exercise of discretion that may arise from a mutually supportive interpretation of the relevant international human rights law. These parties, however, risk missing the synergetic opportunities arising from a more explicit linkage between international biodiversity and human rights law in terms of heightened sense of urgency, enhanced policy coherence, and more widely-shared legitimacy ${ }^{122}$ of international and domestic efforts to implement the Convention.

Times are particularly ripe for such a reflection. CBD parties and stakeholders are developing a new global biodiversity strategy that is expected to guide international cooperation and country- and local-level implementation. ${ }^{123}$ The relevance of biodiversity for the protection and realization of basic human rights could be a key, and certainly, a new element of reflection, especially in light of growing scientific evidence on ${ }^{124}$ and an international policy commitment ${ }^{125}$ to the multiple linkages between biodiversity and human health. In addition, CBD parties are developing a long-term, strategic approach to mainstreaming biodiversity into various production sectors, from agriculture, fisheries and forestry, to infrastructure, energy, mining and health, to feed into the realization of the Sustainable Development Goals ("SDGs"). ${ }^{126}$ They have already adopted consensus guidance on mainstreaming that is noteworthy from a human rights perspective. This guidance makes reference to the promotion of an "equitable and participatory approach to the management and restoration of critical ecosystems" and the recognition of traditional knowledge, including a reference to "cosmo-visions" in the context of mainstreaming biodiversity in the agricultural sector. This guidance also points to the development of legal frameworks or administrative measures for land use to enhance the conservation and sustainable use of biodiversity, while recognizing the rights of indigenous peoples to lands and resources. ${ }^{127}$ As is true for other CBD instruments, the agreed text shies away from human rights language. Nonetheless, it presents elements that can allow for mutually supportive interpretation with relevant and applicable international human rights obligations, in particular with regard to indigenous peoples' rights. Furthermore, CBD parties are discussing the need for new arrangements for indigenous peoples under

121. Id. 99

122. Id. 96

123. See Conference of the Parties to CBD Dec. XIII/1, U.N. Doc. UNEP/CBD/COP/DEC/XIII/1, preambular recital (Dec. 12, 2016).

124. Cristina Romanelli et al., Connecting Global Priorities: Biodiversity and Human Health: A State of KNOWLEDGE REVIEW 200, 214 (2015).

125. See Conference of the Parties to CBD Dec. XII/6 U.N. Doc. UNEP/CBD/COP/DEC/XIII/6, preambular recital para. 3(a) (Dec. 16, 2016).

126. Subsidiary Body on Scientific Technical and Technological Advice to CBD Rec. XXI/4, U.N. Doc. $\mathrm{UNEP} / \mathrm{CBD} / \mathrm{SBSTTA} / \mathrm{REC} / \mathrm{XXI} / 4$, preambular recital, at 3 (Dec. 14, 2017).

127. Conference of the Parties to CBD Dec. XIII/3, U.N. Doc. UNEP/CBD/COP/DEC/XIII/3, preambular recital para. 1 (Dec. 16, 2016). 
the Convention, ${ }^{128}$ taking into account the 2030 Sustainable Development Agenda. There is, therefore, an opportunity to reflect on how the CBD already supports, and discuss how it can better support in the future, efforts to implement the SDGs in a manner consistent with States' obligations under international human rights law, as underscored by the Human Rights Council ${ }^{129}$ and the UN Framework Principles on Human Rights and the Environment. ${ }^{130}$ Recognizing that the SDGs are grounded in international human rights that are dependent on biodiversity can serve to prioritize, and build new alliances around, the CBD objectives.

128. See Working Group on Article 8(j) and Related Provisions of CBD Rec. 10/3, U.N. Doc. UNEP/WG8J/REC/10/3, preambular para. 5(c) (Dec. 16, 2017).

129. Human Rights Council Res. 37/24, U.N. Doc. A/HRC/RES/37/24 (Apr. 13, 2018).

130. Knox, supra note 13, at Framework Principle 2. 